\title{
Investigation of the relationship between levels of oxidative stress markers in the second trimester amniotic fluid with preeclampsia and preterm delivery
}

\author{
Ebru Çelik', Abdullah Karaer1', Ercan Yılmaz', Ilgın Türkçüoğlu', Önder Çelik', Yavuz Şimşek', \\ Pınar KırıcI', Elif Özerol' ${ }^{2}$, Kevser Tanbek ${ }^{2}$ \\ ${ }^{1}$ Department of Obstetrics and Gynecology, Faculty of Medicine, Inönï University, Malatya, Turkey \\ ${ }^{2}$ Biochemistry Department, Inönii University Turgut Özal Research Center, Malatya, Turkey
}

\begin{abstract}
Objective: To determine whether concentrations of oxidative stress markers of amniotic fluid are different in healthy pregnant women from pregnant women with either preeclampsia or preterm birth before 34 weeks gestation.

Methods: This was a retrospective cohort study consisting of consecutive 182 pregnant women with singleton gestations undergoing midtrimester amniocentesis for clinical indications (advanced maternal age, abnormal screening tests for trisomies or maternal request) in İnonü University, Turgut Özal Research Center between April 2011 and May 2012. Patients were invited to donate amniotic fluid for research purposes. The pregnancy outcome was collected by reviewing the charts of hospital or by contacting the patients. Exclusion criteria from the study were: (i) incomplete data about the outcome of pregnancy, (ii) confirmed fetal abnormalities or chromosomal abnormalities, (iii) presence of intrauterine infection, (iv) maternal systemic diseases such as chronic hypertension or diagnosis of gestational diabetes mellitus. Amniotic fluid samples were obtained by transabdominal amniocentesis and $4-5 \mathrm{~mL}$ was collected for research purposes. Amniotic fluid samples were stored at $-80^{\circ} \mathrm{C}$ for the future analysis. Diagnosis of preeclampsia was made according to the criteria of International Society for the Study of Hypertension in Pregnancy.

Results: The mean amniotic fluid concentrations of SOD, ADA, $\mathrm{MPO}, \mathrm{XO}$ and MDA were not different in the preeclamptic group from the control group. Further, the mean concentrations of $\mathrm{SOD}, \mathrm{ADA}, \mathrm{MPO}, \mathrm{XO}$ and MDA in the preterm group were also similar to those in the normal healthy pregnant women.

Conclusion: The oxidative stress markers appear not to be different among the groups. The relation of preterm birth and preeclampsia with oxidative stress and its implication in amniotic environment need to be addressed in further studies.
\end{abstract}

Key words: Oxidative stress, preeclampsia, preterm birth, amniotic fluid.
İkinci trimesterde amniyotik sıvıda oksidatif stres belirteçlerinin düzeyleri ile preeklampsi gelişimi ve erken doğum arasındaki ilişkinin araştırılması

Amaç: Oksidatif stres belirteçlerinin amniyon sıvısındaki konsantrasyonlarının sağlıklı gebeler ile preeklampsi veya 34 haftadan önce erken doğum komplikasyonu gelişen gebeler arasında karşılaştirmak.

Yöntem: Bu çalışma Nisan 2011 ve Mayıs 2012 tarihleri arasında İnönü Üniversitesi Turgut Özal Araştırma Merkezi'nde klinik endikasyonu (ilerlemiş anne yaşı, trizomiler için anormal görüntüleme testleri veya anne isteği) olan gebelere midtrimester amniyosentez yapıldı. Tekiz gebeliği olan toplam 182 kadını içeren retrospektif bir kohort çalışması olan bu çalışmada hastalar, araştırma amaçlı olarak amniyotik sıvı bağışlamaya davet edildiler. Gebelik sonucu, hastane dosyalarından veya hastalara telefon ile ulaşarak toplandı. Çalışma dışında kalma kriterleri; (i) gebeliğin sonucu hakkında eksik veri, (ii) fetal veya kromozomal anomaliler, (iii) intrauterin enfeksiyon varl1ğ1, (iv) kronik hipertansiyon gibi maternal sistemik hastalıklar veya gestasyonel diabet gelişmesi idi. Amniyotik sıvı örnekleri ultrasonografi eşliğinde transabdominal yolla alındı ve araştırma amacıyla 4-5 $\mathrm{mL}$ toplandı ve analiz için $-80^{\circ} \mathrm{C}$ 'de saklandı. Preeklampsi tanıS1, "International Society for the Study of Hypertension in Pregnancy" kriterlerine göre yapildı.

Bulgular: SOD, ADA, MPO, XO ve MDA'nın ortalama amniyotik sivı konsantrasyonları preeklamptik grupta kontrol grubuna göre farklı değildi. Buna ek olarak, SOD, ADA, MPO, XO ve MDA'nın ortalama konsantrasyonları erken doğum grubunda da normal sağlıklı gebe kadınlarla benzer olarak bulundu.

Sonuç: Oksidatif stres belirteçleri gruplar arasında farklı bulunmadi. Erken doğum ve preeklampsi ile oksidatif stresin amniyotik çevredeki etkisi, başka çalışmalarla incelenmelidir.

Anahtar sözcükler: Oksidatif stres, preeklampsi, erken doğum, amniyotik sıvi.
Correspondence: Ebru Çelik, MD. İnönü Üniversitesi

Turgut Özal Tip Merkezi, Malatya, Turkey.

e-mail: ecelik05@googlemail.com

Received: October 18, 2012; Accepted: December 13, 2012
Available online at: www.perinataljournal.com/20120203002 doi:10.2399/prn.12.0203002 QR (Quick Response) Code: 


\section{Introduction}

Oxidative stress plays a key role in the pathophysiology of placenta-related disorders, particularly preeclampsia (PE) and premature delivery. ${ }^{[1]}$ Preeclampsia, which is associated with an increased prenatal and maternal mortality and morbidity, occurs in about $2 \%$ of pregnancies. ${ }^{[2,3]}$ Even though the pathogenesis of pre-eclampsia has still been unclear, defective antioxidant activity may damage vascular endothelium and result in clinical symptoms of preeclampsia (4). Increased levels of oxidative stress and low levels of water-soluble and fat-soluble antioxidants in the plasma have been demonstrated in pregnancy disorders such as preeclampsia and preterm birth. ${ }^{[5,6]}$ In preterm birth, oxidative stress is asserted to cause impairment of collagen through increased reactive oxygen species or antioxidant depletion. ${ }^{[7]}$ Growing evidence suggests that oxidative stress is involved in the pathogenesis of pregnancy disorders associated with placental ischemia, responsible for abnormal placentation. ${ }^{[8,9]}$

The purpose of this study was to compare the degree of oxidative stress in normal pregnancies and in pregnancies complicated with pre-eclampsia and premature births before 34 weeks gestation. We measured antioxidant enzyme activity (superoxide dismutase, adenosine deaminase, myeloperoxidase and xanthine oxide) and free radicals (malondialdehyde). We aimed to potentially determine pregnant women at risk of obstetric complications through the assessment of oxidative stress.

\section{Methods}

This was a retrospective cohort study consisting of consecutive 182 pregnant women with singleton gestations undergoing midtrimester amniocentesis for clinical indications (advanced maternal age, abnormal screening tests for trisomies or maternal request) in İnonü University, Turgut Özal Medical Centre between April 2011 and May 2012. The follow-up chart of participants was presented in Fig. 1.

Patients were invited to donate amniotic fluid for research purposes. The pregnancy outcome was collected by reviewing the charts of hospital or by con-

Patient record flow scheme

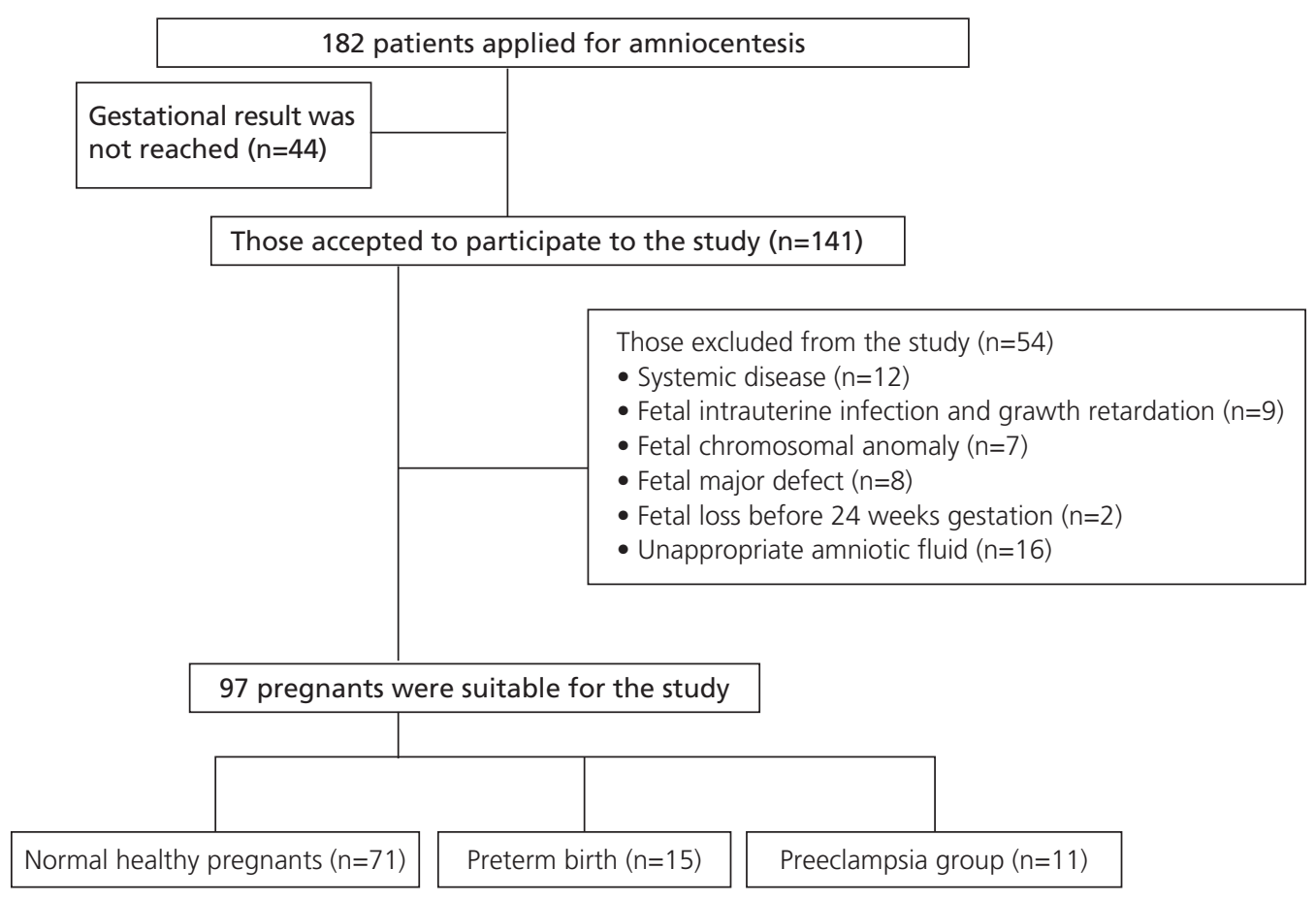

Fig. 1. Patient record scheme. 
tacting the patients. The collection of samples and clinical data was approved by the Institutional Review Boards of Inonu University (Protocol no: 2012/113, 17/07/2012). Written informed consent forms were obtained from all patients. Exclusion criteria from the study were: (i) incomplete data about the outcome of pregnancy, (ii) confirmed fetal abnormalities or chromosomal abnormalities, (iii) presence of intrauterine infection, and (iv) maternal systemic diseases such as chronic hypertension or diagnosis of gestational diabetes mellitus.

Amniotic fluid samples were obtained by transabdominal amniocentesis and 4-5 $\mathrm{mL}$ was collected for research purposes. Amniotic fluid samples were stored at $-80^{\circ} \mathrm{C}$ for the future analysis. Diagnosis of $\mathrm{PE}$ was made according to the criteria of International Society for the Study of Hypertension in Pregnancy. ${ }^{[10]} \mathrm{PE}$ is characterized by systolic blood pressure $\geq 140 \mathrm{mmHg}$ and/or diastolic blood pressure $\geq 90 \mathrm{mmHg}$ on at least two occasions with 4 hour of intervals developing after 20 weeks gestation in previously normotensive women with proteinuria of above $300 \mathrm{mg}$ in 24 hours (or at least two positive readings on dipstick analysis of midstream urine specimens if no available $24-\mathrm{h}$ collection of urine). Spontaneous delivery was defined as vaginal delivery without induction of labor or Cesarean section following spontaneous onset of labor. Although preterm delivery is classically defined as birth before 37 weeks gestation, we used 34 weeks gestation because fetal lung maturation is completed at 34 weeks gestation.

\section{Biochemical analyses}

In order to evaluate the prooxidant-antioxidant balance, the free radicals production were determined by measuring of lipid peroxidation (MDA) levels. Assays were conducted blind to clinical information. The biochemist was blinded to the samples. The amniotic fluid was extracted with an equal volume of an ethanol/chloroform mixture (5:3, volume per volume $[\mathrm{v} / \mathrm{v}])$. After centrifugation at $5000 \mathrm{xg}$ for $30 \mathrm{~min}$, the clear upper layer (the ethanol phase) was collected and used in the SOD activity assay. All preparation procedures were performed at $4^{\circ} \mathrm{C}$. Total $(\mathrm{Cu}-\mathrm{Zn}$ and $\mathrm{Mn}) \mathrm{SOD}(\mathrm{EC}$ 1.15.1.1) activity was determined according to the method of Sun. ${ }^{[1]}$ Amniotic fluid adenosine deaminase (ADA) activity was estimated spectrophotometrically by the method of Giuisti, ${ }^{[12]}$ which is based on the indirect measurements of the formation ammonia, pro- duced when ADA acts in excess of adenosine. Xanthine oxidase (XO) (EC 1.2.3.2) activity was assayed spectrophotometrically by the formation of uric acid from xanthine through the increase in absorbance at 293 $\mathrm{nm} \cdot{ }^{[13]}$ One unit of activity was defined as $1 \mu \mathrm{mol}$ uric acid formed per minute at $37^{\circ} \mathrm{C}$ with $\mathrm{pH}$ 7.5. Malondialdehyde level was determined by a method of Esterbauer and Cheeseman. ${ }^{[14]}$ based on the reaction with thiobarbituric acid (TBA) at $90-100^{\circ} \mathrm{C}$. In the TBA test reaction, malondialdehyde (MDA) or MDAlike substances and TBA react with the production of a pink pigment having an absorption maximum at 532 $\mathrm{nm}$. The reaction was performed at $\mathrm{pH} 2-3$ at $90^{\circ} \mathrm{C}$ for $15 \mathrm{~min}$. The sample was mixed with two volumes of cold $10 \%(\mathrm{w} / \mathrm{v})$ trichloroacetic acid to precipitate protein. The precipitation was pelleted by centrifugation, and an aliquot of the supernatant was reacted with an equal volume of $0.67 \%(\mathrm{w} / \mathrm{v})$ TBA in a boiling water bath for $10 \mathrm{~min}$. After cooling, the absorbance was read at $532 \mathrm{~nm}$. The results were expressed according to a standard graphic that was prepared on the basis of a standard solution (1, 1, 3, 3-tetramethoxypropane).

\section{Statistical analysis}

Data distribution was tested using the KolmogorovSmirnov test. Comparison among the outcome groups was performed using the chi-square test for categorical variables and Mann-Whitney $U$ tests for continuous variables. Data were presented as mean and standard deviation (SD) for continuous variables and as $\mathrm{n}(\%)$ for categorical variables. The statistical software package SPSS 19.0 (SPSS Inc., Chicago, IL, USA) was used for data analyses.

\section{Results}

The clinical and obstetrical characteristics of women with uncomplicated pregnancies (control, $n=71$ ), preeclampsia $(n=15)$ and premature delivery $(n=11)$ are displayed in Table 1. As expected, the normal pregnant women had a higher mean gestational age and birth-weight at delivery than preeclamptic group $(\mathrm{p}<0.001$ and $\mathrm{p}<0.001$, respectively) and preterm group $(\mathrm{p}<0.001$ and $\mathrm{p}<0.001$, respectively) (Table 1). There were no significant differences between women with pregnancy complications and uncomplicated pregnancies regarding to demographic characteristics. The values of serum ADA, SOD, MDA and $\mathrm{XO}$ in women with pre-eclampsia and with preterm birth were not 
Table 1. Comparison of clinical and obstetric characteristics between study groups developing gestational complications and the control group.

\begin{tabular}{lccc} 
& $\begin{array}{c}\text { Preeclampsia group } \\
(\mathbf{n}=\mathbf{1 1})\end{array}$ & $\begin{array}{c}\text { Uncomplicated pregnancies } \\
(\mathbf{n}=\mathbf{7 1})\end{array}$ & $\begin{array}{c}\text { Preterm delivery } \\
(\mathbf{n}=\mathbf{1 5})\end{array}$ \\
Maternal age & $33.18 \pm 5.36$ & $32.66 \pm 5.69$ & $35.07 \pm 2.58$ \\
Nulliparity & $7(63.6 \%)$ & $21(29.6 \%)$ & $2(13.3 \%)$ \\
Gestational age at amniocentesis (weeks) & $18.55 \pm 1.21$ & $18.30 \pm 1.21$ & $18.75 \pm 1.29$ \\
Gestational age at delivery (weeks) & $32.36 \pm 3.20$ & $37.85 \pm 1.70$ & $30.47 \pm 2.59$ \\
Birth-weight (g) & $1959.55 \pm 836.96$ & $3114.30 \pm 461.30$ & $1680.73 \pm 562.38$ \\
Male neonates & $6(54.5 \%)$ & $33(46.5 \%)$ & $7(46.7 \%)$ \\
\hline
\end{tabular}

Table 2. Comparison of the oxidative stress biomarkers among the study and control groups.

\begin{tabular}{lccccc}
$\begin{array}{l}\text { Oxidative stress } \\
\text { biomarkers }\end{array}$ & $\begin{array}{c}\text { Preeclampsia } \\
(\mathbf{n}=\mathbf{1 1})\end{array}$ & $\begin{array}{c}\text { Preterm Birth } \\
(\mathbf{n}=\mathbf{1 5})\end{array}$ & $\begin{array}{c}\text { Controls } \\
(\mathbf{n}=\mathbf{7 1})\end{array}$ & $\mathbf{P}_{1}$ & $\mathbf{P}_{2}$ \\
\hline MPO (mU/g protein) & $12.57 \pm 6.36$ & $11.14 \pm 2.89$ & $12.92 \pm 8.22$ & 0.77 & 0.85 \\
SOD (U/mg protein) & $0.29 \pm 0.18$ & $0.33 \pm 0.28$ & $0.28 \pm 0.17$ & 0.91 & 0.80 \\
XO (U/g protein) & $0.96 \pm 0.59$ & $0.85 \pm 0.55$ & $1.07 \pm 0.73$ & 0.95 & 0.64 \\
ADA (U/g protein) & $0.09 \pm 0.09$ & $0.07 \pm 0.10$ & $0.05 \pm 0.035$ & 0.34 & 0.39 \\
MDA (nmol/g protein) & $0.49 \pm 0.42$ & $0.52 \pm 0.40$ & $0.43 \pm 0.38$ & 0.65 & 0.82 \\
\hline
\end{tabular}

Measurements of various oxidative stress markers, including amniotic fluid SOD, MPO, XO, ADA and MDA activity at 16 to 21 weeks gestation in women who developed subsequent pregnancy complications and those with uncomplicated pregnancies. The values are represented as mean and standard deviation. P1 value was presented for comparison between women with uncomplicated pregnancies and those with preeclampsia. P2 values were presented for comparison between women with uncomplicated pregnancies and those with preterm birth.

statistically different from the controls (Table 2). The values of MPO in the pathological pregnancies and in the preterm labor were also similar to the control group $(\mathrm{p}=0.59)$.

\section{Discussion}

In this study, we have observed similar values of oxidative stress indicators in amniotic fluid samples obtained at midtrimester in women who subsequently developed preeclampsia and delivered prematurely compared with women who delivered without any gestational complication. Likewise, similar amniotic fluid myeloperoxidase concentrations were noted in women with complicated pregnancies and control group. An uncomplicated pregnancy is a pro-oxidant state, which is characterized with equilibrium between free antioxidants and oxidative stress. Oxidative stress has been previously proposed as a mediator of preterm birth, but biomarkers of oxidative stress have not been noted in either amniotic fluid of preterm or term pregnancies.
Although there is an imbalance between antioxidant activity and oxidative stress markers as gestation advances, antioxidant production decreases when gestation achieves term. ${ }^{[15,16]}$ Therefore, in this study, we attempted to prove that oxidative stress biomarkers in amniotic fluid could be an indicator for pathological pregnancies. However, we observed no differences in the concentrations of oxidative stress between pregnancies developing preeclampsia and resulting with preterm birth and uncomplicated pregnancies.

It has been demonstrated that antioxidants can be measured in the amniotic fluid, but in much lower concentrations compared to serum. ${ }^{[17]}$ The explanation of the discrepancy of our findings with the previous studies may be that we did not evaluate the serum concentrations of antioxidants. Several studies have noted the association of maternal oxidative stress biomarkers at the early pregnancy with pregnancy complications. A study on longitudinal analysis serum samples obtained from 18-22 weeks gestation until birth of baby at 4 week intervals has demonstrated a trend tending to 
increase concentrations of oxidative stress markers in pregnancies complicated with preeclampsia. ${ }^{[17]}$

A recent meta-analysis has reported that serum concentrations of MDA, an end-product of lipid peroxidation, were significantly higher in pregnancies complicated with preeclampsia when compared to those in normal pregnancies. ${ }^{[18]}$ However, Bogavac et al. found contradicting results that MDA levels were low in amniotic fluid of women with preeclampsia. ${ }^{[19]}$ We noted concentrations of MDA and XOD in women with complicated pregnancies were similar to those with normal pregnancies, which is not in correlation with alteration of oxidative stress in the pregnancies with preeclampsia. ${ }^{[18,19]}$ Additionally, levels of SOD, intracellular enzyme of antioxidative defense, remain alike in the women with complicated pregnancies, which is in agreement with the previous study. ${ }^{[1,20]}$ The concentrations of ADA, which is present in all human tissue and regarded as a cellular inflammatory indicator, were previously detected higher in plasma of women with preeclampsia than normal healthy pregnancies. ${ }^{[21]}$ However, our result again was not in accordance with published literature data. The explanation of this discrepancy may be that we did not measure plasma levels of ADA and the gestational week of sample collection was different from the previous study.

Oxidative stress has been suggested to be one of the main pathological processes involved in the preterm premature rupture of membrane (PPROM). The association of endogenous antioxidant status with premature rupture of membrane was studied. The plasma levels of MDA were found to be higher, and SOD and GSH were lower in women with PPROM than those in healthy subjects. ${ }^{[2]}$ There were, however, a conflicting results reported by Hsieh et al. that there were no differences in the plasma levels of SOD activity between women with uncomplicated pregnancies and those who delivered prematurely. ${ }^{[20]}$ We also found that the levels of antioxidants and lipid peroxidation in the premature birth group were similar to those in the healthy control group, which is in line with the previous data.

There are some limitations in the current study. First, in this study, we recruited participants at 19 to 21 weeks gestation when they were screened for preterm birth. It is arguable that this timing of examination would be early for investigating the pathophysiology of preterm birth. Second, we did not assess the placentas.
However, all amniotic fluid had been collected in this hospital, but the majority of study population did not deliver in the same institution and as a consequence, it was not possible to obtain an adequate number of placentas for investigating the role of oxidative stress in the underlying pathology of complicated pregnancy. Third limitation is a relatively small number of patients. The lack of these statistically significant findings between study and control groups for a relatively common finding raises possibility that the result occurred due to a Type I (alpha) error. Further, the study was underpowered $(<80 \%)$ to detect a difference in oxidative stress biomarkers, as having 11 and 15 patients in the study groups.

\section{Conclusion}

In summary, we did not find any differences in oxidative stress biomarkers between women with uncomplicated pregnancies and those who subsequently developed pregnancy complications. This study may suggest that the oxidative stress markers appears not to have early impact on the development of pregnancy related complications, but considering our findings, it is difficult to state the implication of high oxidative stress on the pathogenesis of pregnancy related complications. Nevertheless, future studies are required to examine whether biomarkers of oxidative stress in amniotic fluid can be used as a screening to determine pregnant women at a high risk for those complications.

Conflicts of Interest: No conflicts declared.

\section{References}

1. Gupta S, Agarwal A, Banerjee J, Alvarez J. The role of oxidative stress in spontaneous abortion and recurrent pregnancy loss: a systematic review. Obstet Gynecol Survey 2007;62:335-47.

2. WHO. Make every mother and child count. Geneva: WHO; 2005.

3. Cantwell R, Clutton-Brock T, Cooper G, et al. Saving Mothers' Lives: reviewing maternal deaths to make motherhood safer: 2006-2008. The Eighth Report of the Confidential Enquiries into Maternal Deaths in the United Kingdom. BJOG 2011;118 Suppl 1:S1-S203.

4. Sağol S, Ozkinay E, Ozşener S. Impaired antioxidant activity in women with preeclampsia. Int J Gynaecol Obstet 1999;64:121-7.

5. Krishna Mohan S, Venkataramana G. Status of lipid peroxidation, glutathione, ascorbic acid, vitamin $\mathrm{E}$ and antioxidant 
enzymes in patients with pregnancy-induced hypertension. Indian J Physiol Pharmacol 2007;51:284-8.

6. Longini M, Perrone S, Vezzosi P, et al. Association between oxidative stress in pregnancy and preterm premature rupture of membranes. Clin Biochem 2007;40:793-7.

7. Wall PD, Pressman EK, Woods JR Jr. Preterm premature rupture of the membranes and antioxidants: the free radical connection. J Perinatal Med 2002;30:447-57.

8. Abrahams VM, Kim YM, Straszewski SL, Romero R.Mor G. Macrophages and apoptotic cell clearance during pregnancy. Am J Reprod Immunol 2004;51:275-82.

9. Sargent IL, Germain SJ, Sacks GP, Kumar S, Redman CW.Trophoblast deportation and the maternal inflammatory response in preeclampsia. J Reprod Immunol 2003;59:153-60.

10. Davey DA, MacGillivray I. The classification and definition of the hypertensive disorders of pregnancy. Am J Obstet Gynecol 1988;158:892-8.

11- Sun Y, Oberley LW, Li Y. A simple method for clinical assay of superoxide dismutase. Clin Chem 1988;34:497-500.

12. Giusti G. Adenosine deaminase. In: Bergmeyer MV, editor. Methods of enzymatic analysis. 2nd ed. New York: Academic Press; 1974. p. 1092-8.

13. Prajda N, Weber G. Malignant transformation-linked imbalance: decreased xanthine oxidase activity in hepatomas. FEBS Lett 1975;59:245-9.

14. Esterbauer H, Cheeseman KH. Determination of aldehydic lipid peroxidation products: malonaldehyde and 4-hydroxynonenal. Methods Enzymol 1990;186:407-21.
15. Gitto E, Reiter RJ, Karbownik M, Tan DX, Gitto P, Barberi $\mathrm{S}$, et al. Causes of oxidative stress in the pre- and perinatal period. Biol Neonate 2002;81:146-57.

16. Watson AL, Palmer ME, Jauniaux E, Burton GJ. Variations in expression of copper/zinc superoxide dismutase in villous trophoblast of the human placenta with gestational age. Placenta 1997;18:295-9.

17. Chappell LC, Seed PT, Briley A. A longitudinal study of biochemical variables in women at risk of preeclampsia. Am J Obstet Gynecol 2002;187:127-36.

18. Gupta S, Aziz N, Sekhon L. Lipid peroxidation and antioxidant status in preeclampsia: a systematic review. Obstet Gynecol Surv 2009;64:750-9.

19. Bogavac M, Lakic N, Simin N, Nikolic A, Sudji J, Bozin B. Biomarkers of oxidative stress in amniotic fluid and complications in pregnancy. J Matern Fetal Neonatal Med 2012;25:104-8.

20. Hsieh TT, Chen SF, Lo LM, Li MJ, Yeh YL, Hung TH. The association between maternal oxidative stress at midgestation and subsequent pregnancy complications. Reprod Sci 2012;19:505-12.

21. Karabulut AB, Kafkasli A, Burak F, Gozukara EM. Maternal and fetal plasma adenosine deaminase, xanthine oxidase and malondialdehyde levels in pre-eclampsia. Cell Biochem Funct 2005;23:279-83.

22. Yin B, Zhen M. Lipid peroxidation in plasma and the activity of superoxide dismutase (SOD) in pregnant women with premature rupture of membrane. Zhonghua Yi Xue Za Zhi $1995 ; 75: 463-5,509$. 